\title{
Controlled Clinical Evaluation of Bruhaniya Ganasiddha Kshirpan and Kshirbasti in the Management of Garbhashosh with Special Reference to IUGR
}

\author{
${ }^{1}$ Dr.Surekha J.Dewaikar (M.D.PhD Scholor), ${ }^{2}$ Dr.Sarika Shinde \\ ${ }^{I}$ M.D., Ph D. Scholar, Professor \& H. O. D., Streerog-Prasutitantra Dept., R. A. Podar Medical College, \\ Worli, Mumbai-1 \\ ${ }^{2}$ Ex. M. S. Scholar R. A. Podar Medical College, Streerog Prasutitantra Dept.
}

\begin{abstract}
Controlled clinical evaluation of Bruhaniya Gana (Shatavari, Kakoli, Kshirkakoli, Bala, Ashwgandha, Vidari, Tiltaila, Gokshir, Goghrita, Sita and Madhu) siddha Kshirpan and Kshirbasti with Alamine SN and Cap.Alamine forte in the management of Garbhashosh (IUGR) in 60 subjects for a period of 15 days was done. The study was conducted over a period of 2 years at M.A.Podar (Ayu) Hospital, Mumbai, by Dept. of Streerog Prasutitantra.

After treatment it was observed by statistical analysis that, in IUGR, Bruhaniya ganasiddha ksheerbasti along with ksheerapan has better effect over drug Alamine Forte. Trial group showed improvement in weakness, fatigues, general debility etc., the newborn baby shows improvement in the birth weight and complexion. This shows that basti improves quality of life of mother along with fetus.
\end{abstract}

\section{Introduction}

IUGR is defined as babies with birth weight below the tenth percentile for a given gestational age for a given population as a result of pathological restriction in their ability to grow. In Ayurvedic text, Garbhashosh is also stated as 'Vatabhipanna garbha' in term, it can be defined as underdevelopment or under nourishment of part or whole body of the fetus in utero. While describing specific management of garbhashosh, Sushruta suggested use of kshirbasti and medhyanna.

( Tayo bruhanavataghna madhur dravya sanskrute: ghrutkshir rasaistruptiraamagarbh shcha khadayet ! - Va.Sha. 2/17 )

Garbhashosho cha vatanam kshiram paramucchhate !

- Ka. Khi. Bhojankalpadhyay

Milk treated with yashtimadhu, kashmari and sita is advised by Ashtangsangrahkar and Charakacharya especially for garbhoshosh. It provides nourishment and stability to fetus in utero.

Concept of fetal well being has gained importance in conventional science in recent era but this concept of 'supraja janana' was a prime concern of Ayurveda since old era. Different disorders affecting fetal health along with its treatment such as Upvishtaka, Nagodara, Garbhakshaya, garbhashosh are described in depth. Intrauterine growth restriction (Garbhashosh) is a major public health problem in most of the developing countries. Most frequently it is related to conditions like poverty, chronic malnutrition and placental insufficiency in mother. Undernutrition is one of the most common but correctable cause of Garbhashosh i.e. IUGR in developing countries like India.

At present, there is no proven therapy in modern science for reversing growth restriction. $\mathrm{O}_{2}$ therapy, high protein diet, hydration, hyperalimentation in form of transamniotic or intravenous route can be given as a treatment.

Therefore present study is entitled, "Controlled clinical evaluation of Bruhaniyagana siddha kshirpan and kshirbasti in the management of Garbhashosh w.s.r. to IUGR".

\section{Material and Methods:}

Study type

Consent

Study Centre
Open randomized controlled study.

An informed written consent of all 60 patients.

- Patients were selected from OPD and IPD of

M. A. Podar Hospital, Worli, Mumbai. 


\section{Groups of Management:}

$\begin{array}{lll}\text { Group A } & : & \text { Trial group. } \\ \text { No. of patients } & : & 30 . \\ \text { Treatment } & : & \text { Brihaniyagana Siddha kshirpan and kshirbasti. } \\ \text { Dose } & : & 80 \mathrm{ml} \text { kshirpan by oral route and } 400 \mathrm{ml} \\ \text { Kshirbasti by transrectal route, daily. } & \\ \text { Duration of treatment } & : & 15 \text { days. } \\ \text { Group B } & : & \text { Control group. } \\ \text { No. of patients } & : & 30 . \\ \text { Treatment } & : & \text { Inj. Alamine SN and Cap Alamine Forte. } \\ \text { Dose } & : & \begin{array}{l}\text { Cap Alamine Forte orally twice daily and Inj. Alamine SN } \\ \text { 200ml by Intravenous route, on every } 4^{\text {th }} \text { day of five }\end{array} \\ \text { Duration of treatment } & : & \text { consecutive cycles. }\end{array}$

Criteria for diagnosis and assessment:

Patients having sign of Garbhashosh were assessed with respect to following point and clinical parameters like Ultrasound examination. Detailed physical examinations of all strotsa were done. All necessary laboratory investigations were done. If necessary, colour Doppler scan was done. Clinical parameters like maternal weight, abdominal girth and fundal height were taken. Ultrasound based parameters such as AC, FL, AFW and PI were taken before and after treatment.

\section{Inclusion Criteria :}

1. All the pregnant women with IUGR, having more than 28 wks of gestation.

2. Patients having age between $18-35$ yrs.

3. Patients having $\mathrm{Hb} \%$ more than $7 \mathrm{gm} \%$.

\section{Exclusion Criteria :}

1. Patients with less than 28 weeks of gestation.

2. Multiple pregnancies.

3. Patients having $\mathrm{Hb} \%$ less than $7 \mathrm{gm} \%$.

4. Patients having cyanotic heart disease.

5. Patients having STDs.

6. Patients having diabetes mellitus.

7. Patients of abruption placenta

Clinical Parameters : $\quad \mathrm{AG}-$ Abdominal Girth in $\mathrm{cm}$, $\mathrm{FH}-$ Fundal Height in $\mathrm{cm}$.

Ultrasound parameters: $\mathrm{AC}-\mathrm{Abdominal}$ Circumference.,

AFI - Amniotic Fluid Index.

AFW - Approximate Fetal Weight.,

PI - Ponderal Index.

Total effect of therapy :

The total effect of therapy was concluded on the basis of relief in percentage.

1. Upashaya - Total relief and improvement in all parameters such as AFI, AFW, AC, PI, AG and FH. 
2. Anupashaya -

Those patients presenting no improvement in their parameters.

\section{Drug Review:}

\section{Steps of Preparation of Kshirpak for Kshirbasti:}

Bhruhaniya Ganasiddha Kshirpak was prepared for kshirbasti and kshirpan as per the method mentioned in sharangadhara samhita.

Bharad churna (coarse powder) of shatawari, ashwagandha, bala, kakoli, kshirkakoli, vidarikanda and sita each were taken 3 gms. Gokshir (cow milk) was taken $160 \mathrm{ml}$ and water $640 \mathrm{ml}$,tiltail,cowghee,honey $80 \mathrm{ml}$ each added to it and kshirpak prepared as per Shargdhar samhita..Sukhoshna (Lukewarm) kshirpak, was well churned using churning staff.

\section{Kshirbastidan karma}

Patient was taken in its left lateral position with right knee flexed on empty stomach. Sthanika snehana of guda was done with cotton deeped in tiltaila. $400 \mathrm{ml}$ of koshna bastidravya, was taken in enema pot, simple rubber catheter was applied at its tip. Catheter was then introduced in to guda and complete bastidravya was allowed to pass in slowly. Patient then advised to remain in left lateral position for one hour and to take food when she desire.

\section{Preparation of Bhruhaniya Ganasiddha Kshirpak for Kshirpan:}

Bharadachurna of the all above mentioned dravyas were taken $1.5 \mathrm{gms}$ of each along with $80 \mathrm{ml}$ ksheera and $320 \mathrm{ml}$ of water and ksheerpak was prepared as per sharagdhara.

Mode of action of Bruhaniya gana siddha kshirbasti and kshirpan :-

Table showing Rasa, Virya, Vipaka, Guna and Doshaghnata of Bruhaniya gana sidha kshir

\begin{tabular}{|c|c|c|c|c|c|c|c|c|c|c|c|c|c|}
\hline $\begin{array}{l}\text { Sr. } \\
\text { no }\end{array}$ & Properties & 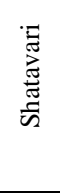 & 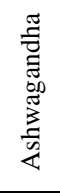 & $\frac{\tilde{a}}{\tilde{\pi}}$ & 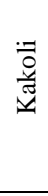 & 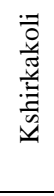 & 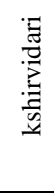 & 䍃 & 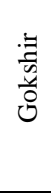 & 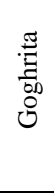 & 䔍 & 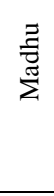 & $\begin{array}{l}\text { Bhruhania } \\
\text { ganasidha } \\
\text { kshir }\end{array}$ \\
\hline 1 & Madhura rasa & + & + & + & + & + & + & + & + & + & + & + & $11+$ \\
\hline 2 & Kashaya & - & - & - & - & - & - & - & + & - & + & + & $3+$ \\
\hline 3 & Katu & - & + & - & - & - & - & - & - & - & + & - & $2+$ \\
\hline 4 & Tikta & + & + & - & - & - & - & - & - & - & - & - & $2+$ \\
\hline 5 & Ushna virya & - & + & - & - & - & - & - & - & - & + & - & $1+$ \\
\hline 6 & Sheeta virya & + & - & + & + & + & + & + & + & + & - & + & $8+$ \\
\hline 7 & Madhuravipaka & + & + & + & + & + & + & + & + & + & - & - & $8+$ \\
\hline 8 & Katu vipaka & - & - & - & - & - & - & - & - & - & + & + & $2+$ \\
\hline 9 & Sheeta guna & - & - & - & + & + & + & + & + & + & + & - & $7+$ \\
\hline 10 & Snigdha guna & + & + & + & + & + & + & + & + & + & + & - & $10+$ \\
\hline 11 & Laghu guna & - & + & + & - & - & - & - & - & - & - & + & $3+$ \\
\hline 12 & Guru guna & + & - & - & + & + & + & + & + & + & + & - & $8+$ \\
\hline 13 & Vatghna & + & + & + & + & + & + & + & + & + & + & + & $11+$ \\
\hline 14 & Pittaghna & + & + & + & + & + & + & + & + & + & + & + & $11+$ \\
\hline 15 & Kaphagana & - & + & + & - & - & - & - & - & + & + & + & $5+$ \\
\hline
\end{tabular}

\section{Mechnism of action-Bruhaniya gana siddha kshirbasti and kshirpan}




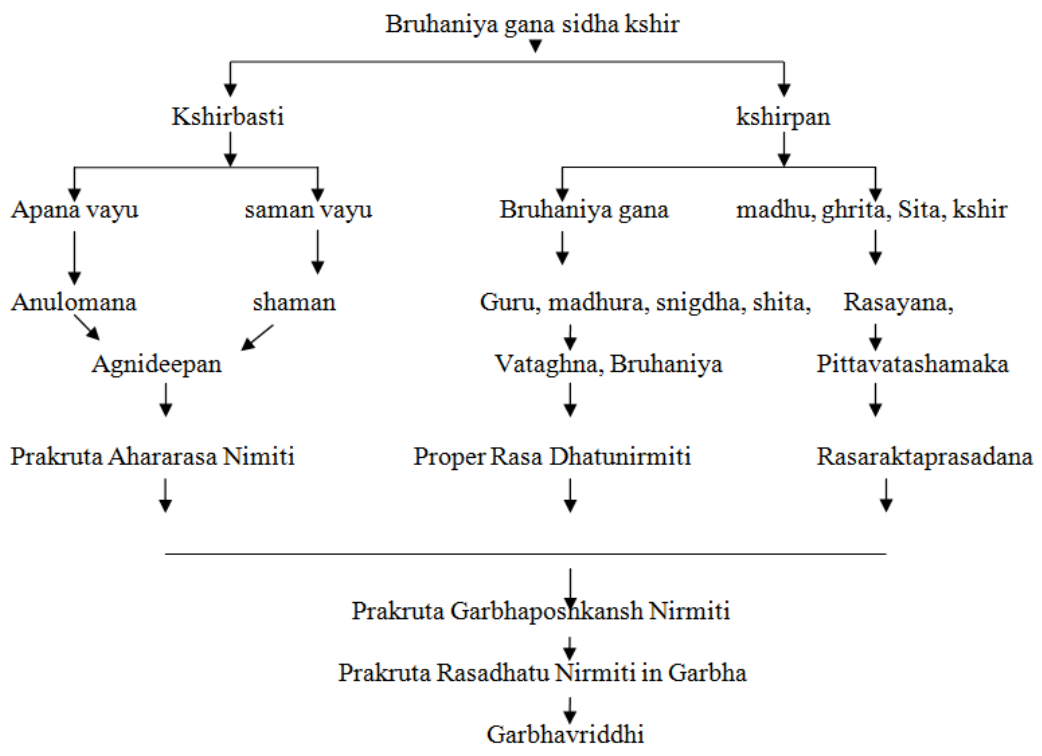

Mode of action of Bruhaniya gana siddha kshirbasti and kshirpan:

Garbhashosh is Rasakshayaja vyadhi. The main etiopathological process has less dominance of Jatharagni which leads to Apachita ahararasa nirmiti, various disorders related to Rasadushti which causes Rasakshaya. Here similarities and contradictions are used together to maintain equilibrium which is the basic aim of treatment. So for the management of Garbhashosh we should have a formulation having following properties.

Vataghna, pittaghna, sheetavirya, Madhura rasa, Madhura vipaka, snigdha, sheeta, guru etc. Guna.

All the above mentioned properties are found in Bruhaniya gana sidha kshir which is used for kshirbasti and kshirpan. Thus the drug formulation Bruhaniya gana sidha kshir has dominance of snigdha, sheeta, guru guna, sheeta virya, madhura rasa, madhura vipaka, pruthvi - Aapa mahabhutadhikya, vata shaman and anuloman properties which leads to agnideepan, it helps for prakruta aharasanirmiti, prakruta rasadhatunirmiti and Rasaprasadana. In this way our aim of Garbhavridhi is achieved.

\section{B.Control Group}

Modern Drug Review:-

1) Cap. Alamine Fort

2) Inj. Alamin SN

\section{Composition}

- $\quad$ Cap. Alamine Forte -

Presentation - each capsule contains,
L-leucine $-18.3 \mathrm{mg}$
L-threonine
L-isoleucine
L-lycine
L-valine
L-phenylalanine
L-tryptophan
Copper sulphate pentahydrate $-1.0 \mathrm{mg}$
L-methonine
Manganese sulphate monohydrate $-4.6 \mathrm{mg}$
Light magnesium oxide $-30 \mathrm{mg}$
Selenium dioxide monohydrate $-75.0 \mathrm{mg}$

- Inj. Alamin SN

Presentation - infusion bottle of $200 \mathrm{ml}$, each $200 \mathrm{ml}$ contain
L-isoleucine - 560mg
L-lycine HCL-1100mg
L-threonine-650mg
L-tryptophan-130mg
L-Arginine HCL-955mg
L-cysteine HCL-145mg
L-histidine HCL-811mg

\author{
L-leucine - 1250mg \\ L-methonine-350mg \\ L-phenylalanine-935mg \\ L-valine-450mg \\ L-asparatic acid-380mg \\ L-glutamic acid-650mg \\ L-proline-3L-serine-220mg
}



L-tyrosine-35mg
L-alanine-620mg
Glycine-1070mg
Xylitol-5.0gm

E/N Ratio $=1.04: 1$

Total amino acid $=10.641 \mathrm{gm} / 100 \mathrm{ml}$

Mode of action -

Amino acid plays vital role in the development of healthy fetus

Formation of new tissues

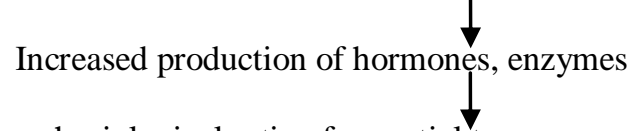

Maintaining physiological ratio of essential to nonessential Amino acids.

Indications: IUGR,

Oligohydramnios,

Contraindications: Cardiac insufficiency,

Maternal malnutrition.

Irreversible liver damage.

Adverse drug effects:

Nausea, vomiting, chest discomfort, acidosis, chill, headache, etc.

\section{Dosage \& administration :}

Cap. Alamine Forte twice daily for 15 days

Inj. Alamine SN 200ml IV on Every $4^{\text {th }}$ day

\section{Drug standardization:}

Analytical study of drug sample was done in the standard lab Shree Dhootpapeshwar Pvt. Ltd

A) Phytochemical study of Bhruhaniya gana sidha kshir.

\begin{tabular}{|l|l|l|}
\hline Sr. No & Parameters & Result \\
\hline 1 & Description & Off white colour liquid Suspension \\
\hline 2 & Loss on drying & $2.96 \%$ \\
\hline 3 & Total Ash & $0.31 \%$ \\
\hline 4 & Acid insoluble ash & $0.01 \%$ \\
\hline 5 & $\mathrm{pH}$ & $6.18 \%$ \\
\hline 6 & Total solids & 34.68 \\
\hline
\end{tabular}

B) HPTLC study of Bhruhaniya gana siddha kshir.

Identification and authentification of the ayurvedic drugs was done from recognized pharmaceutical company. HPTLC of the phytotherapy final product was done. Result of HPTLC Graph of Bhruhaniya Ganasiddha kshir shows peaks, which match with standard peaks of the raw material used eg. Shatavari, ashwagandha, etc. as they were present in the Bhruhaniya Ganasiddha kshir. Therefore, we can conclude that all the raw materials were present in the Bhruhaniya Ganasiddha kshir.

Observation and Results :

Table - 1Showing Age wise distribution of 60 pregnant women with Asym - IUGR

\begin{tabular}{|l|l|l|l|l|l|l|}
\hline \multirow{2}{*}{ Age Group } & \multicolumn{2}{|l|}{ Trial Group } & \multicolumn{2}{l|}{ Control Group } & \multicolumn{2}{l|}{ Total } \\
\cline { 2 - 7 } & No. of Pt & $\%$ & No. of Pt & $\%$ & No. of Pt & $\%$ \\
\hline 18-20 Years & 4 & 13.33 & 7 & 23.33 & 11 & 18.33 \\
\hline $21-25$ years & 12 & 40.00 & 8 & 26.66 & 20 & 33.33 \\
\hline 26-30 years & 11 & 36.66 & 12 & 40.00 & 23 & 38.33 \\
\hline 31-35 years & 3 & 10.00 & 3 & 10.00 & 6 & 10.00 \\
\hline
\end{tabular}

Table - 2 Showing Socio-economic status wise distributions of 60 patients Of Asym - IUGR

\begin{tabular}{|l|l|l|l|l|l|l|}
\hline \multirow{2}{*}{$\begin{array}{l}\text { Socio-economic } \\
\text { status }\end{array}$} & Trial Group & \multicolumn{1}{l}{ Control Group } & Total \\
\cline { 2 - 7 } & No. of Pt & $\%$ & No. of Pt & $\%$ & No. of Pt & $\%$ \\
\hline Lower & 19 & 63.33 & 15 & 50.00 & 34 & 56.66 \\
\hline Middle & 9 & 30.00 & 11 & 36.66 & 20 & 33.33 \\
\hline High & 2 & 6.66 & 4 & 13.33 & 6 & 10.00 \\
\hline
\end{tabular}


Table - $3 \quad$ Showing Gravida wise distributions of patients of Asym - IUGR

\begin{tabular}{|l|l|l|l|l|l|l|}
\hline \multirow{2}{*}{ Gravida } & \multicolumn{2}{|l|}{ Trial Group } & \multicolumn{2}{l|}{ Control Group } & \multicolumn{2}{l|}{ Total } \\
\cline { 2 - 7 } & No. of Pt & $\%$ & No. of Pt & $\%$ & No. of Pt & $\%$ \\
\hline Primi & 9 & 30.00 & 8 & 26.66 & 17 & 28.33 \\
\hline Second & 10 & 33.33 & 12 & 40.00 & 22 & 36.66 \\
\hline Multi & 11 & 36.66 & 10 & 33.33 & 21 & 35.00 \\
\hline
\end{tabular}

Table -4 Showing Quantity of diet wise distribution of 60 patients of Asym - IUGR

\begin{tabular}{|l|l|l|l|l|l|l|l|}
\hline \multirow{2}{*}{ Sr.No. } & \multirow{2}{*}{ Quantity of diet } & Trial group & Control group & \multicolumn{2}{l|}{ Total } \\
\cline { 3 - 8 } & & No.of Pt & \% & No.of Pt & \% & No.of Pt & \% \\
\hline 1 & Poor & 18 & 60.00 & 13 & 43.33 & 31 & 51.00 \\
\hline 2 & Moderate & 7 & 23.33 & 8 & 26.66 & 15 & 25.00 \\
\hline 3 & Good & 5 & 16.66 & 9 & 30.00 & 14 & 23.33 \\
\hline
\end{tabular}

Table - 5 Showing dominant rasa in diet wise distribution of 60 patients of Asym - IUGR

\begin{tabular}{|c|c|c|c|c|c|c|c|}
\hline \multirow[t]{2}{*}{ Sr.No } & \multirow{2}{*}{$\begin{array}{l}\text { Dominant } \\
\text { rasa in diet }\end{array}$} & \multicolumn{2}{|c|}{ Trial group } & \multicolumn{2}{|c|}{ Control group } & \multicolumn{2}{|l|}{ Total } \\
\hline & & No.of Pt & $\%$ & No.of Pt & $\%$ & No.of Pt & $\%$ \\
\hline 1 & Madhur & 4 & 13.33 & 3 & 10.00 & 7 & 11.66 \\
\hline 2 & Amla & 3 & 10.00 & 4 & 13.33 & 7 & 11.66 \\
\hline 4. & Katu & 9 & 30.00 & 9 & 30.00 & 18 & 30.00 \\
\hline 5. & Tikta & 7 & 23.33 & 6 & 20.00 & 13 & 21.66 \\
\hline 6. & Kashay & 5 & 16.66 & 6 & 20.00 & 11 & 18.33 \\
\hline
\end{tabular}

Table-6 Showing Prakrutiwise distribution of the 60 patients of Asym - IUGR

\begin{tabular}{|c|c|c|c|c|c|c|c|}
\hline \multirow[t]{2}{*}{ Sr.No. } & \multirow[t]{2}{*}{ Type Of Prakruti } & \multicolumn{2}{|c|}{ Trial group } & \multicolumn{2}{|c|}{ Control group } & \multicolumn{2}{|l|}{ Total } \\
\hline & & No.of $\mathrm{Pt}$ & $\%$ & No.of $\mathrm{Pt}$ & $\%$ & No.of $\mathrm{Pt}$ & $\%$ \\
\hline 1 & $\mathrm{VP}$ & 14 & 46.66 & 13 & 43.33 & 27 & 45.00 \\
\hline 2 & PK & 7 & 23.33 & 11 & 36.66 & 18 & 30.00 \\
\hline 3 & $\mathrm{KV}$ & 9 & 30.00 & 6 & 20.00 & 15 & 25.00 \\
\hline
\end{tabular}

Table -7 Showing liquor status at $1^{\text {st }}$ visit of 60 patients of Asym - IUGR

\begin{tabular}{|l|l|l|l|l|l|l|}
\hline \multirow{2}{*}{ Liquor } & \multicolumn{2}{|l|}{ Trial Group } & \multicolumn{2}{l|}{ Control Group } & \multicolumn{3}{l|}{ Total } \\
\cline { 2 - 7 } & No.of Pt & $\%$ & No.of Pt & $\mathbf{\%}$ & $\begin{array}{l}\text { No.of } \\
\text { Pt }\end{array}$ & \% \\
\hline Oligo & 16 & 53.33 & 19 & 63.33 & 35 & 58.33 \\
\hline Adequate & 8 & 26.66 & 8 & 26.66 & 16 & 26.66 \\
\hline Poly & 6 & 20.00 & 3 & 15.00 & 9 & 15.00 \\
\hline
\end{tabular}

Table $-\mathbf{8} \quad$ Showing H/o P/v bleeding of 60 patients of Asym - IUGR

\begin{tabular}{|c|c|c|c|c|c|c|}
\hline \multirow[t]{2}{*}{ H/o P/v bleeding } & \multicolumn{2}{|c|}{ Trial Group } & \multicolumn{2}{|c|}{ Control Group } & \multicolumn{2}{|l|}{ Total } \\
\hline & No.of $\mathrm{Pt}$ & $\%$ & No.of Pt & $\%$ & $\begin{array}{l}\text { No.of } \\
\text { Pt }\end{array}$ & $\%$ \\
\hline Yes & 10 & 33.33 & 14 & 46.66 & 24 & 40 \\
\hline No & 20 & 66.66 & 16 & 53.33 & 36 & 60 \\
\hline
\end{tabular}

Table-9 Showing distribution of period of gestation of 60 patients of Asym - IUGR

\begin{tabular}{|l|l|l|l|l|l|l|}
\hline \multirow{2}{*}{$\begin{array}{l}\text { Period of } \\
\text { Gestation }\end{array}$} & \multicolumn{2}{|l|}{ Trial Group } & \multicolumn{2}{l|}{ Control Group } & \multicolumn{2}{|l|}{ Total } \\
\cline { 2 - 7 } & $\begin{array}{l}\text { No.of } \\
\text { Pt }\end{array}$ & $\%$ & No.of Pt & $\%$ & $\begin{array}{l}\text { No.of } \\
\text { Pt }\end{array}$ & $\%$ \\
\hline 29 to 33 weeks & 13 & 43.33 & 9 & 30.00 & 22 & 36.66 \\
\hline 33 to 38 weeks & 17 & 56.66 & 21 & 70.00 & 38 & 63.33 \\
\hline
\end{tabular}

Table - 10Showing effect of parameters of 30 patients of Garbhashosh of trial group by Paired' $t$ ' test

\begin{tabular}{|l|l|l|l|l|l|l|l|}
\hline \multirow{2}{*}{ Sr. o } & Parameter & \multicolumn{2}{|l|}{ Mean+SD } & Mean of diff + SD & SE d & t & \\
\cline { 3 - 7 } & & BT & AT & & & \\
\hline 1 & FH & $28.433+3.104$ & $32+3.833$ & $3.56+2.582$ & 0.472 & 7.555 \\
\hline 2 & AG & $86.033+6.031$ & $88.667+6.326$ & $2.633+2.189$ & 0.400 & 6.580 & $<0.001$ \\
\hline 3 & AC & $25.840+2.421$ & $28.981+2.734$ & $3.141+1.387$ & 0.254 & 12.389 & $<0.001$ \\
\hline 4 & AFI & $8.2+2.592$ & $11.133+2.255$ & $2.933+2.116$ & 0.387 & 7.582 & $<0.001$ \\
\hline 5 & AFW & $1709.633+433.72$ & $2240.8+516.605$ & $531.16+206.74$ & 37.795 & 14.054 & $<0.001$ \\
& & 9 & & & & & \\
\hline 6 & PI & $6.909+0.968$ & $7.839+0.530$ & $0.930+0.902$ & 0.165 & 5.640 & $<0.001$ \\
\hline
\end{tabular}


Effect of therapy on parameters was statistically evaluated in trial group by paired " $t$ " test as follows:-

$\mathrm{FH}, \mathrm{AG}, \mathrm{AC}$ AFI, AFW and PI were tested " $\mathrm{t}$ " value in trial group before starting the treatment and after treatment. " $\mathrm{t}$ " value and $\mathrm{P}$ value $(\mathrm{P}<0.001$ in each parameter), is highly significant.

Table - 11Showing effect on parameters of 30 patients of Garbhashosh of control group by

Paired " $\mathrm{t}$ " test.

\begin{tabular}{|c|c|c|c|c|c|c|c|}
\hline \multirow{2}{*}{$\begin{array}{l}\text { Sr. } \\
\text { No }\end{array}$} & \multirow[t]{2}{*}{ Parameter } & \multicolumn{2}{|l|}{ Mean+SD } & \multirow{2}{*}{$\begin{array}{l}\text { Mean of diff }+ \\
\text { SD }\end{array}$} & \multirow[t]{2}{*}{ SE d } & \multirow[t]{2}{*}{$\mathrm{t}$} & \multirow{2}{*}{$\mathrm{p}$} \\
\hline & & $\mathrm{Bt}$ & AT & & & & \\
\hline 1 & $\mathrm{FH}$ & $28.87+3.16$ & $30.33+3.273$ & $1.46 \pm 0.681$ & 0.1250 & 11.773 & $<0.001$ \\
\hline 2 & $\mathrm{AG}$ & $82.067+5.401$ & $84.166+4.060$ & $2.1 \pm 3.799$ & 0.6946 & 3.0321 & $<0.001$ \\
\hline 3 & $\mathrm{AC}$ & $25.94+1.778$ & $27.981+2.006$ & $1.6153 \pm 1.668$ & 0.3049 & 5.2964 & $<0.001$ \\
\hline 4 & AFI & $8.126+2.567$ & $9.366 \pm 2.182$ & $1.24 \pm 2.710$ & 0.4954 & 2.5028 & $<0.001$ \\
\hline 5 & AFW & $1716.23+341.40$ & $2092.63 \pm 303.64$ & $376.4 \pm 178.412$ & 32.616 & 11.5401 & $<0.001$ \\
\hline 6 & PI & $7.213+0.3157$ & $7.672 \pm 0.4030$ & $0.460 \pm 0.313$ & 0.057 & 8.046 & $<0.001$ \\
\hline
\end{tabular}

Effect of therapy on parameters before treatment and after treatment was statistically evaluated in control group by paired " $\mathrm{t}$ " test as follows:-

$\mathrm{FH}, \mathrm{AG}, \mathrm{AC}, \mathrm{AFI}, \mathrm{AFW}$ and PI in control group were tested " $\mathrm{t}$ " value, which were found highly significant in each parameter.

Table - $12 \quad$ Showing total effect of therapy on 60 patients of Garbhashosh

\begin{tabular}{|l|l|l|l|l|l|l|}
\hline \multirow{2}{*}{$\begin{array}{l}\text { Total effect of } \\
\text { therapy }\end{array}$} & Trial Group & Control Group & Total effect of therapy \\
\cline { 2 - 7 } & No. of Pts & $\%$ & No. of Pts & $\%$ & No. of Pts \\
\hline Upashaya & 25 & $83.33 \%$ & 21 & $70 \%$ & 46 & $76.66 \%$ \\
\hline Anupashaya & 2 & $16.66 \%$ & 9 & $30 \%$ & 14 & $23.33 \%$ \\
\hline
\end{tabular}

\section{Discussion}

This was an effort to form the ladder towards Basti Chikitsa in Garbhini, which was not frequently practiced before. Total 60 pregnant women were registered in present clinical study. More no. of patients was found in the 34-38 weeks of gestational age. Maximum patients belonged to 26-30 years age group. Most of the Asymmetric IUGR patients were second para. IUGR patients had Katu Rasa predominant \& poor quantity of diet. IUGR was mostly associated with Vata Pitta pradhan Prakriti.

The drug formulation Bruhaniya gana sidha kshir has dominance of Snigdha, Sheeta, guru guna, sheeta virya, madhura rasa, madhura vipaka, pruthvi-aapa mahabhutadhikya, vata shaman and anuloman properties which leads to agnideepan, it helps prakruta aharrasanirmiti, prakruta rarsadhatunirmiti and Rasaprasadana. In this way our aim of Garbhavridhi is achieved.

\section{Conclusion}

It can be stated that bruhaniya gana sidha kshirbasti and kshirpan can be given to a pregnant women with IUGR after completion of $28^{\text {th }}$ weeks of gestation, without any complication either in mother or in child. It is cost effective as compared to modern drug.

Effects of kshirbasti are sukhaprasavakara and improving Garbhadharan kala. These effects of basti need to be assessed with various investigations and large sample size.

\section{References}

[1]. Ashtanga Hridayam with Sarvanga Sundar Vyakhya of Arundutta and Ayurveda Rasayana Vyakhya of Hemadri (Sanskrit) chowkhamba Surbharati Prakashan, Varnasi, 1997.

[2]. Ashtanga Sangrahah with Sarvanga Sundar Vykhya of Pt.Lalchandra Shastry Vaidya (Hindi), Baidyanath Ayurveda Bhavan Private Ltd., $1^{\text {st }}$ Edition 1989.

[3]. Charaka Samhita with Nibandha Sangrah Vyakhya of Dalhana (Sanskrit), Chaukhamba Orientails, Varanasi.

[4]. Text book of obstetrics - D.C.Dutta, 1990.

[5]. Williom's obstetrics

[6]. Kashyap Samhita Khilsthana.

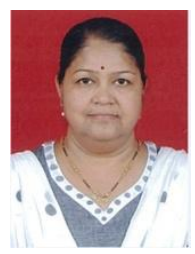

Dr.Surekha J.Dewaikar (M.D.PhD Scholor),

M.D., Ph D. Scholar, Professor \& H. O. D., Streerog-Prasutitantra Dept., R. A. Podar Medical College, Worli, Mumbai-1 